\title{
Exploitative Innovation and the Impact of Realized Absorptive Capability and Technology Orientation
}

\author{
Nertila Busho \\ PhD. Candidate. Department of Management, Faculty of Economy, University of Tirana, \\ Albania \\ Daniela Lena
}

PhD. Candidate. Department of Economics and Social Scientist (DiSES), Faculty of Economy "Giorgio Fuà", Marche Polytechnic University, Ancona, Italy

\begin{abstract}
This paper aims to identify the impact of Technology Orientation on the relationship of Realized Absorptive Capability and Exploitative Innovation. Using a sample of 194 firms located in Albania, we empirically test the mediating role of Technology Orientation. Nowadays, Innovation is not anymore a new phenomenon. In the literature a lot of studies have seen it with a close connection to technology. In some other study, in case of a dynamic environment, firms with realized absorptive capability are more predisposed to absorb technology and to be able to be update with it. Since technology is considered as an auxiliary tool to innovation, we considered it specifically for exploitative innovation which can increase even the efficiency of firms. The focus of this study is placed on knowledge-intensive sector in order to better capture the effect of these variables. The results demonstrate that the Technology Orientation has a full mediating role on this relationship. The Realized Absorptive Capability has not any impact on Exploitative Innovation in case of the lack of Technology Orientation.
\end{abstract}

Keywords: Realized Absorptive Capability, Technology Orientation, Exploitative Innovation, Albanian firms, Knowledge based industry.

\section{Introduction}

The business environment has become increasingly sophisticated and restricted. Therefore, it is complicated, given the fast changes in business environment nowadays, for an organization to create all the required knowledge to obtain the required innovation. One of the earliest authors that has write about innovation is Schumpeter (1934), he referees to it as a new combination of existing resources. As pointed out by Teece (2007), resource-based theory laid the micro foundations of the necessary skills to maintain firms' superior performance in a dynamic environment with high innovation. In the same line $\mathrm{Hu}, 2014)$ determines that a higher organizational ability to acquire and utilize new information leads to a higher capacity to launch innovations.

There is no doubt that the importance of innovation is directly related to performance as Drucker (1985) describe the innovation leads to changes that creates a new dimension of 
performance. So, most of the literature that investigate on innovation concepts and its role in firms' success, gives an importance role of innovation and frequently cites it as the key element of superior firm performance (Han, Kim, \& Srivastava, 1998; Hurley \& Hult, 1998; Weerawardena, O'Cass, \& Julian, 2006).

\section{Content details}

Previous literature classified the innovation along two dimensions: (1) degree of novelty of new or existing technologies, products, and services that firms introduce into market before their own competitors (it may have already been available in other markets); and (2) degree of novelty of new or existing technologies, products, and services that firms introduce, but are already available from competitors in firms' market (Popadić M., Černe, M., 2016). This can also be associated also to the concept of incremental and radical innovations (L.A.G. Oerlemans et al, 2013).

Among the literature on innovation an important role was given to the concept of exploratory and exploitative innovation. The notion of exploratory and exploitative innovation is seen as continuum of the concept of exploration and exploitation (Popadić M., Černe, M., 2016). March (1991) introduced the two concepts as follows: exploration includes things captured by terms such as search, variation, risk taking, experimentation, flexibility, discovery, and innovation. Exploitation includes such things as refinement, choice, production, efficiency, selection, implementation, and execution. The concept of exploration-exploitation is scarce with respect to technological innovations and thus is needed. In past, exploration-exploitation was linked through mergers and acquisitions, alliances, and other strategic changes (Lavie \& Rosenkopf, 2006), with little attention given to the innovations (Greve, 2007).

Popadić et al. in their paper in 2016 made a clear distinguish between exploration and exploitation in innovation context. In doing so, they considered exploration and exploitation as outcomes of innovation, and exploratory innovation was seen as synonymous with radical innovation, while exploitative innovation with incremental innovation. Exploratory innovations are radical innovations because they are designed to meet the needs of new markets (Benner \& Tushman, 2003; Danneels, 2002). For example, development of a distribution channel that is new to the market is a form of exploratory innovation. In turn, exploitative innovations are incremental innovations and designed to serve existing markets (Benner \& Tushman, 2003). For instance, improving the efficiency of existing distribution channels is a form of exploitative innovations.

Exploratory innovations require development of new knowledge (Benner \& Tushman, 2002). They enable firms to scan a variety of opportunities from the environment and create capabilities that are necessary for long-term survival and prosperity (Uotila, Maula, Keil, \& Zahra, 2009). Moreover, exploratory innovation transposes in new processes, products, or markets (Lumpkin \& Dess, 1996). In turn, the goal of exploitative innovation is to build a firm's current competitive advantage by efficiently managing the firm's existing resources, skills, and capabilities to improve the designs of current products and services or to strengthen current customer relationships (Lubatkinet al., 2006; Sirén, Kohtamäki, \& Kuckertz, 2012). So, through exploitation, firms learn how to exploit existing technologies while through exploration, firms are more focus to experiment, and innovate (Levinthal and March, 1993; Jansen et al., 2006). In some study both exploratory innovation and exploitative innovation have a positive effect 
on firm performance for example, this is found at (Jansen et., al 2006; Li et al., 2008; Rothaermel and Alexandre, 2009; Junni et al., 2013).

According to previous studies in this field, many internal factors facilitate exploratory innovation and exploitative innovation. The main that can be mentioned are the Absorptive capacity (AC) in its two dimensions' potential absorptive capacity and realized absorptive capacity and the third variable Technological innovation (Mikhailov, A., \& Reichert, F. M. 2019). Considering Teece (2010) the technological development is the key of success to captured customer needs as well as the value creation, if a new product or service is implemented in a firm, so in a dynamic environment this factor is very related with innovation. $\mathrm{AC}$ and innovation studies show that AC positively affects innovative performance. Cohen and Levinthal (1990, p. 128) define AC as "the ability of a firm to recognize the value of new, external information, assimilate it, and apply it to commercial ends". They stated that research and development (R\&D) spillovers can increase the firms' ability to identify, assimilate and exploit knowledge from the environment. While Zahra and George (2002) provided another turn to the definition, they are separating the AC structure into two main dimensions: potential absorptive capacity (PACAP) and realized absorptive capacity (RACAP).

PACAP includes the acquisition and assimilation capabilities. It makes the firm open to the acquisition and assimilation of externally-generated knowledge (Lane and Lubatkin, 1998). On the other hand, RACAP involves the transformation and exploitation capabilities discussed earlier. It reflects the firm's capacity to leverage the knowledge that has been absorbed.

Based on Jansen et al., 2006 the absorptive capacity begins with knowledge acquisition from the environment and ends with its exploitation. Even if PACAP and RACAP have different roles, yet their effect is not isolated, but rather complementary. Both subsets of absorptive capacity coexist and participate in the improvement of firm performance. Firms cannot possibly exploit knowledge without first acquiring it. Similarly, firms can acquire and assimilate knowledge but might not have the capability of transforming and exploiting this knowledge for profit generation. Therefore, a high PACAP does not necessarily imply enhanced performance. RACAP involves transforming and exploiting the assimilated knowledge by incorporating it into the firm's operation (A.L. Leal-Rodríguez et al, 2014).

The focus of our study is the exploitative innovation as Albania's firm are much more oriented in incremental innovations based on the reason that the firms on this developing county don't have the possibility to change rapidly the technology and to develop the exploratory innovation but they are more focused to implement new technology and new process that requires their market, so they are investing in existing needs customers or markets, current and existing distribution channels. We want to investigate the impact of realized absorptive capability on Exploitative innovation. In addition, this study sheds light on the mediating role of technology oriented on Exploitative innovation.

Hence, we pose the hypotheses and theoretical model as below:

H1. There is a significant relationship on Realized Absorptive Capability and Exploitative Innovation. 
H2. There is a significant relationship between Realized Absorptive Capability and Technological Orientation

H3. Realized Absorptive Capability and Technology Orientation both impact positively Exploitative Innovation

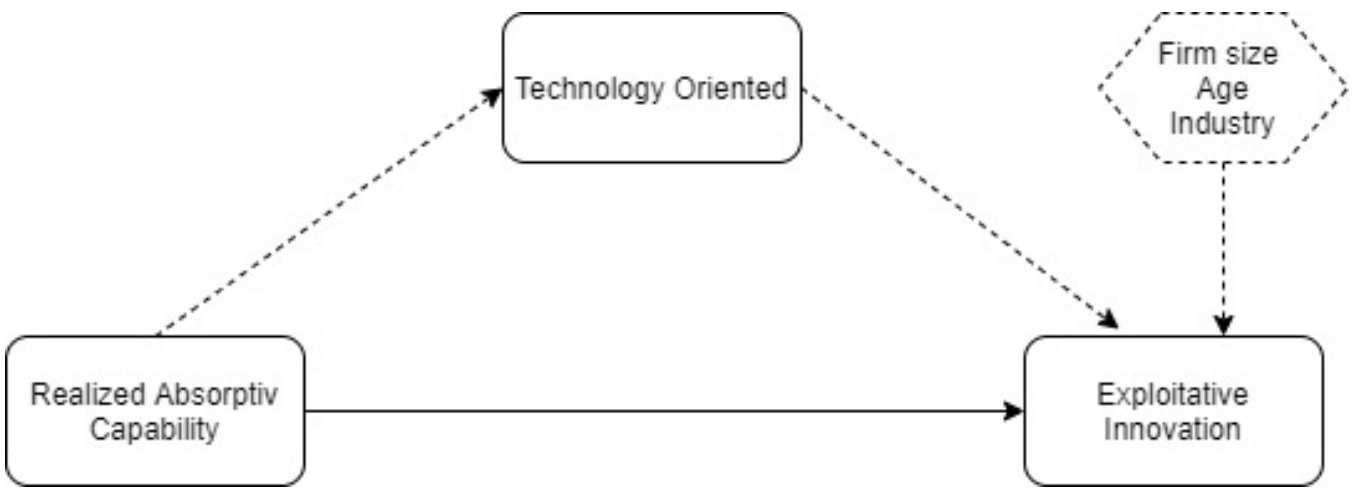

Fig 1: Theoretical structure model

\section{Method and procedures}

The sample in this study consists of 203 firms randomly selected from a defined framework of companies registered in the national business center in Albania on 2018. This framework was focused only on intensive knowledge sectors. According to the definition of the Eurostat on NACE Rev.2 the sample has considered nine different subsectors in manufacturing and services. The main reason for selectin only the intensive knowledge sectors was to capture the phenomenon under investigation about innovation (Von Nordenflycht, 2010). As Ashworth (2012) and Morollon, Loscos and Pardos (2010) explain the firms with high concentration of knowledge, information, technology and skills are more adapted to supplying solutions on a dynamic environment. Based on Bayesian outlier we removed nine cases, so the final analyze is made for 194 businesses. The most data are taken directly by the owners, administrators or firms managers, when we have been explained all the questions face by face. The Statistical Package for Social Sciences (SPSS) version 20 was used to analyze the data.

\section{Dependent variable}

Exploitative Innovation based on (Jansen et al. 2006) is measured on four questions with seven-point scale, related only with the new product and services. The manager was asked to rate if their firms refine the provision of existing products and services; if their implement regularly small adoptions to existing products and services; if they introduce improved, but existing products and services for the local market and if the organization expands services for existing clients. The four-item construct yielded a Cronbach Alpha of 0.752 (standardized Cronbach Alpha coefficients), follows thin accordance with the recommended criteria (Nunnally,1978) and (Hair et al., 2006) show that coefficients of 0.7 or more are considered adequate.

\section{Independent variable}

Realized Absorptive Capacity is operationalized on six items based on (Camisón \& Forés, 2010; Flatten et al., 2011). The six items generate a Cronbach Alpha of 0.855 that is a very good 
indicator for the construct. The firm managers have been asked to measure the items from 1 (if they were strongly disagreeing) to 7 (if they were strongly agreeing). They are asked for: 1. The ability that their employees have to structure and use newly collected information, 2 . If the employees are used to preparing newly collected information for further purposes and making it available, 3 . Are they able to integrate new information into their work; 4 . Do they have immediate access to stored information, e.g. about new or changed guidelines or instructions; 5. Are they regularly engage in the development of prototypes or new concepts; and 6 do they apply new knowledge in the workplace to respond quickly to environment changes.

\section{Mediated variable}

Technology orientation is the independent variable that we have operationalized based on Zhou et al (2005). The three items that are used for this construct are based on the activity that firms are using. So the managers had value the: 1 . the use of the most advanced technology in the development of new products; 2 . Easy acceptance by the organization of technological innovation which is undertaken based on concrete results of a research work and 3. Technological innovation is easily accepted in the management of specific projects undertaken in the organization. The items generate a Cronbach Alpha of 0.742 that is a good indicator according to (Hair et al., 2006).

\section{Control Variable:}

Manufacture or service - this variable is measured as a dichotomy variable, the business are divided on service and manufacturing based on classification of NACE2.

Age - is the number of the years that the business has on the market.

Size of business - is measured by the logarithm of the employees that has the business.

Empirical model

Following Baron and Kenny (1986), a system of three equations is used to assess the meditational role of realized absorptive capability:

1) $\mathrm{Y}=\beta 10+\beta 11 \mathrm{X}+\mathrm{e} 1$

2) $\mathrm{Me}=\beta 20+\beta 21 \mathrm{X}+\mathrm{e} 2$

3) $\mathrm{Y}=\beta 30+\beta 31 \mathrm{X}+\beta 32 \mathrm{Me}+\mathrm{e} 3$

Where, in this article $\mathrm{Y}$ is the dependent variable representing - firm's performance, $\mathrm{X}$ is the independent variable - the technology orientation and Me is the mediator variable-realized absorptive capability.

\section{Construct validity}

To analyze the items that are used in the questionnaire we performed a factor analysis with varimax rotation (see appendix A). To test the validity of our independent perceptual variables is used KMO and Bartlett's Test that is significant and has an adequacy measured of Sampling 0.783 . The two components accounted $61.89 \%$ of the variance and loadings are above the acceptable standard of 0.32 proposed by Tabachnick and Fiddell (2007).

The results for Technology Orientation loaded reasonably high, exactly $(.633, .860, .890)$. Also four the construct of Realized Absorptive Capability the items reasonable high $(.843, .776$, 
$.871, .759,785, .835)$. About the Exploitative innovation the items loaded also high $(.852, .610$, $.800, .774)$.

\section{Results}

We have considered only 194 business after we have eliminated the outlier. The respondents on this study were the owners, administrators or managers of the business where $35.1 \%$ of the respondents were female and $64.9 \%$ were male. Around $80 \%$ of business were located on Tirana, the capital city of Albania, and the other businesses were located in Durres that is also a city with a lot of businesses because of the impact that has the location of port in this city. In Albania, based on Instat (2020) around 41\% of the businesses are located inside of this two cities. Most of the businesses interviewd are service focused and only $28.4 \%$ are manufacturing businesses. Even if the sample is randomly selected, the representation of the population is at a good level, refering to the age and division into production and service according to Eurostat (Nace2), as shown in the table below:

Table 4: Comparison in \% between Sample and Campion

\begin{tabular}{|c|c|c|c|c|c|c|c|c|c|}
\hline & \multicolumn{2}{|c|}{ Based on NACE2 (\%) } & \multicolumn{7}{c|}{ Age (\%) } \\
\hline & Manufacture & Service & $\begin{array}{c}1-5 \\
\text { year }\end{array}$ & $\begin{array}{c}6-10 \\
\text { year }\end{array}$ & $\begin{array}{c}11-15 \\
\text { year }\end{array}$ & $\begin{array}{c}16-20 \\
\text { year }\end{array}$ & $\begin{array}{c}21-25 \\
\text { year }\end{array}$ & $\begin{array}{c}26- \\
30 \\
\text { year }\end{array}$ & $\begin{array}{c}\text { Over } \\
30 \\
\text { years }\end{array}$ \\
\hline $\begin{array}{c}\text { Sample } \\
(194)\end{array}$ & 28.4 & 71.6 & 32.1 & 25.2 & 16.8 & 11.8 & 10.1 & 2.5 & 1.5 \\
\hline $\begin{array}{c}\text { Campion } \\
(3493)\end{array}$ & 29.3 & 70.7 & 23.11 & 23.11 & 18.09 & 16.08 & 13.06 & 5.05 & 1.5 \\
\hline
\end{tabular}

Sobel test is performed to see the significant of the mediation effect on this equation. Based on the value of skewness and kurtosis the variable define as a normal distribution. The value of VIF are greater than one so this indicate a lack of multicolinarity. The following tables summarizes all the regression results for the three hypotheses:

Table 5: Regression results for $\mathrm{H} 1$ and $\mathrm{H} 2$

\begin{tabular}{|c|c|c|c|c|c|c|}
\hline & \multicolumn{3}{|c|}{$\begin{array}{c}\text { Dependent variable: Exploratory } \\
\text { Innovation } \\
\text { H1 } \\
\end{array}$} & \multicolumn{3}{|c|}{$\begin{array}{c}\text { Dependent variable: } \\
\text { Technology Orientation } \\
\text { H2 } \\
\end{array}$} \\
\hline Variable & $\mathrm{B}$ & S.E & Beta & $\mathrm{B}$ & S.E & Beta \\
\hline Constant & $4.792^{* * *}$ & .417 & & $3.575^{* * *}$ & .442 & \\
\hline $\begin{array}{c}\text { Realized Absorptive } \\
\text { Capability }\end{array}$ & $.186^{*}$ & .072 & .182 & $.331^{* * *}$ & .077 & .297 \\
\hline R Square & \multicolumn{3}{|c|}{.033} & \multicolumn{3}{|c|}{.088} \\
\hline Adjusting R Square & \multicolumn{3}{|c|}{.028} & \multicolumn{3}{|c|}{.084} \\
\hline $\mathrm{F}$ & \multicolumn{3}{|c|}{6.609} & \multicolumn{3}{|c|}{18.613} \\
\hline
\end{tabular}

$* 0.01 \leq \mathbf{p}<0.05,{ }^{* *} \mathbf{p}<0.01,{ }^{* * *} \mathrm{p}<0.001,+0.05 \leq \mathrm{p}<0.1$

Table 6: Regression results for $\mathrm{H3}$

\begin{tabular}{|c|c|c|c|}
\hline & \multicolumn{3}{|c|}{ Dependent variable: Exploitative Innovation H3 } \\
\hline & (RealizAC-TO-EXIn) & (RealCA-TO-EXIn) & (RealCA-TO-EXIn) \\
\hline
\end{tabular}




\begin{tabular}{|c|c|c|c|c|c|c|c|c|c|}
\hline Variable & B & S.E & Beta & $\mathrm{B}$ & S.E & Beta & $\mathrm{B}$ & S.E & Beta \\
\hline Constant & $\begin{array}{c}3.694^{* *} \\
*\end{array}$ & $\begin{array}{c}.45 \\
7\end{array}$ & & $\begin{array}{c}3.627^{* *} \\
*\end{array}$ & $\begin{array}{c}.45 \\
5\end{array}$ & & $\begin{array}{c}3.360^{* *} \\
*\end{array}$ & $\begin{array}{c}.54 \\
2\end{array}$ & \\
\hline $\begin{array}{l}\text { Realized Absorptive } \\
\text { Capability }\end{array}$ & .084 & $\begin{array}{c}.07 \\
2\end{array}$ & .083 & .060 & $\begin{array}{c}.07 \\
2\end{array}$ & .059 & .052 & $\begin{array}{c}.07 \\
5\end{array}$ & .051 \\
\hline $\begin{array}{l}\text { Technology } \\
\text { Orientation }\end{array}$ & $.307^{* * *}$ & $\begin{array}{c}.06 \\
4\end{array}$ & .336 & $.304^{* * *}$ & $\begin{array}{c}.06 \\
4\end{array}$ & .332 & $.314^{* * *}$ & $\begin{array}{c}.06 \\
4\end{array}$ & .348 \\
\hline $\begin{array}{c}\text { Industry } \\
\text { (service/manufacture) }\end{array}$ & & & & $.310 \dagger$ & $\begin{array}{c}.16 \\
3 \\
\end{array}$ & .129 & $.373^{*}$ & $\begin{array}{c}.16 \\
9 \\
\end{array}$ & .157 \\
\hline Firm Size & & & & & & & .070 & $\begin{array}{c}.05 \\
3 \\
\end{array}$ & .099 \\
\hline Age & & & & & & & -.002 & $\begin{array}{c}.00 \\
9\end{array}$ & $\begin{array}{c}- \\
.015 \\
\end{array}$ \\
\hline$R$ Square & & 36 & & & 152 & & & 69 & \\
\hline Adjusting R Square & & 27 & & & 139 & & & 46 & \\
\hline$F$ & & 042 & & & .361 & & & 219 & \\
\hline
\end{tabular}

$* 0.01 \leq \mathrm{p}<0.05, * * \mathrm{p}<0.01,{ }^{* * *} \mathrm{p}<0.001,+0.05 \leq \mathrm{p}<0.1$

Hypothesis 1: Realized Absorptive Capability has a positive impact on Exploitative Innovation. The R-square indicates that around $3.3 \%$ of the variance variable can be explained in this model.

Hypothesis 2: Realized Absorptive Capability has a significant positive impact on Technological Orientation. The R-square in this model indicate that around $8.8 \%$ of the variance can be explained in this model.

Hypothesis 3: In the model that we can see both Realized Absorptive Capability and Technology Orientation, they don't have both significant impact on Exploitative Innovation. Only the Technology Orientation has a significant positive impact on Exploitative Innovation. The Rsquare in this model indicate that around $15.2 \%$ of the variance can be explained in this model.

Based on (Baron and Kenny, 1986) as it is a significant relationship between the Realized Absorptive Capability on Exploitative Innovation (equation 1) and there is a significant relationship between Realized Absorptive Capability to the Technology Orientation (equation 2) we come to the conclusion that Technology Orientation is a complete mediator in this relation because the effect of the independent variable (Realized Absorptive Capability) is not significant on the Exploitative Innovation (equation 3) when is taken in consideration also Technology Orientation.

\section{Conclusions}

Our study aims to investigate the relationship between realized absorptive capability and exploitative innovation in 194 firms focused on knowledge intensive sector on Albania. As well known in many studies. technology is often seen as the main input of innovation or even as an essential element to make it successful. At the same time, as it is emphasized by the resource based theory, the firm cannot gain sustainable competitive advantages without dynamic capabilities in such a dynamic environment. Viewing the technology orientation as an important variable on innovation this study has concluded that no matter how important realized absorptive capability is, they cannot be transferred their potential to exploitative innovation without the mediation role of technology. So, based on this empirical study, the firms that follow the market and also tend to be innovative must be conscious that the main 
element on this process is the access of technology or how they are oriented on technology to achieve their goals. Also the study has managerial implication, they should know that no matter how many resources and potential a firm has, if technological orientation is lacking the resources may be left unused.

\section{Limitation}

No studies come without limitations, so some limitations of our research should be noted. One of the limitations of the study is related to innovation, our study includes only exploitative innovation and does not include the explorative innovation. Another limitation of this study is the lack of other variable that explain exploitative innovation. Finally, in the future study more data are needed to ensure that the captured effect is the same.

\section{References}

[1] Ashworth, S. (2012). Electoral accountability: Recent theoretical and empirical work. Annual Review of Political Science, 15, 183-201.

[2] Baron, R. M., \& Kenny, D. A. (1986). The moderator-mediator variable distinction in social psychological research: Conceptual, strategic, and statistical considerations. Journal of personality and social psychology, 51(6), 1173.

[3] Benner, M. J., \& Tushman, M. (2002). Process management and technological innovation: A longitudinal study of the photography and paint industries. Administrative Science Quarterly, 47, 676-707

[4] Camisón, C., \& Forés, B. (2010). Knowledge absorptive capacity: New insights for its conceptualization and measurement. Journal of Business Research, 63(7), 707-715.

[5] Cohen, W. M., \& Levinthal, D. A. (1990). Absorptive capacity: A new perspective on learning and innovation. Administrative Science Quarterly, 35(1), 128-152. doi:10.2307/2393553

[6] Drucker, P. F. (1985). The changed world economy. Foreign Aff., 64, 768.

[7] Flatten, T. C., Engelen, A., Zahra, S. A., \& Brettel, M. (2011). A measure of absorptive capacity: Scale development and validation. European Management Journal, 29(2), 98-116.

[8] Greve, H. R. (2007). Exploration and exploitation in product innovation. Industrial and Corporate Change, 16, 945-975

[9] Hair, J. F., Black, W. C., Babin, B. J., Anderson, R. E., \& Tatham, R. (2006). Multivariate data analysis . Uppersaddle River.

[10] Han, J. K., Kim, N., \& Srivastava, R. K. (1998). Market orientation and organizational performance: Is innovation a missing link? Journal of Marketing, 62, 30-45.

[11] Hu, B. (2014). Linking business models with technological innovation performance through organizational learning. European Management Journal, 32(4), 587-595.

[12] Hurley, R., \& Hult, G. T. M. (1998). Innovation, market orientation, and organizational learning: an integration and empirical examination. Journal of Marketing, 62, 42-54.

[13] Jansen, J. J., Van Den Bosch, F. A., \& Volberda, H. W. (2006). Exploratory innovation, exploitative innovation, and performance: Effects of organizational antecedents and environmental moderators. Management science, 52(11), 1661-1674.

[14] Junni, P., Sarala, R. M., Taras, V., \& Tarba, S. Y. (2013). Organizational ambidexterity and performance: A meta-analysis. Academy of Management Perspectives, 27(4), 299-312. 
[15] L. Leal-Rodríguez L. A., L. Roldán L. J., Ariza-Montes A. J.c , Leal-Millán A., (2014), From potential absorptive capacity to innovation outcomes in project teams: The conditional mediating role of the realized absorptive capacity in a relational learning context, International Journal of Project Management 32 894-907

[16] Lavie, D., \& Miller, S. (2008). Alliance portfolio internationalization and firm performance. Organization Science, 19, 623-646

[17] Levinthal, D. A., \& March, J. G. (1993). The myopia of learning. Strategic management journal, 14(S2), 95-112.

[18] Li, C. R., Lin, C. J., \& Chu, C. P. (2008). The nature of market orientation and the ambidexterity of innovations. Management Decision, 46, 1002-1026.

[19] Lubatkin, M. H., Simsek, Z., Ling, Y., \& Veiga, J. F. (2006). Ambidexterity and performance in small to medium-sized firms: The pivotal role of top management team behavioral integration. Journal of Management, 32, 646-672.

[20] March, J.G. (1991) Exploration and Exploitation in Organizational Learning. Organization Science, 2, 71-87.

[21] Mikhailov, A., \& Reichert, F. M. (2019). Influence of absorptive capacity on innovation: A systematic literature review. Revista de Administração Mackenzie, 20(6). doi:10.1590/ 1678-6971/eRAMD190033

[22] Morollón, F. R., Loscos, A. G., \& PARDOS, E. (2010). The effects of KIBS outsourcing on Aragon firms' efficiency. Estudios de Economía Aplicada, 28(1), 1-22.

[23] Nunnally, J. C. (1978). Psychometric Theory: 2d Ed. McGraw-Hill.

[24] Oerlemans, L.A.G., Knoben J, Pretorius M.W., Alliance portfolio diversity, radical and incremental innovation: The moderating role of technology management, Technovation 33, 234-246

[25] P.J. Lane, M. Lubatkin Relative absorptive capacity and interorganizational learning Strateg. Manag. J., 19 (1998), pp. 461-477

[26] Popadić, M., Černe, M., (2016). Exploratory and exploitative innovation: the moderating role of partner geographic diversity. Economic Research-Ekonomska Istraživanja, 29:1, 1165-1181, DOI: 10.1080/1331677X.2016.1211951

[27] Rothaermel, F. T., \& Alexandre, M. T. (2009). Ambidexterity in technology sourcing: The moderating role of absorptive capacity. Organization science, 20(4), 759-780.

[28] Schumpeter, J. A. (1934). The theory of economic development, translated by Redvers Opie. Harvard: Economic Studies, 46, 1600-0404.

[29] Tabachnick, B. G., Fidell, L. S., \& Ullman, J. B. (2007). Using multivariate statistics (Vol. 5, pp. 481-498). Boston, MA: Pearson.

[30] Teece, D. J. (2007). Explicating dynamic capabilities: the nature and microfoundations of (sustainable) enterprise performance. Strategic management journal, 28(13), 1319-1350.

[31] Teece, D. J. (2010). Business models, business strategy and innovation. Long range planning, 43(2-3), 172-194.

[32] Uotila, J., Maula, M. V. J., Keil, T., \& Zahra, S. A. (2009). Exploration, exploitation, and financial performance: Analysis of S\&P 500 corporations. Strategic Management Journal, 30, 221-231

[33] Von Nordenflycht, A. (2010). What is a professional service firm? Toward a theory and taxonomy of knowledge-intensive firms. Academy of management Review, 35(1), 155-174. 
[34] Weerawardena, J., O'Cass, A., \& Julian, C. (2006). Does industry matter? Examining the role of industry structure and organizational learning in innovation and brand performance. Journal of Business Research, 59(1), 37-45.

[35] Zahra, S. A. \& George, G., (2002). Absorptive Capacity: A review, Reconceptualization, and Extension. Academy of Management Review, 27(2), 185203.

[36] Zhou, K. Z., Yim, C. K., \& Tse, D. K. (2005). The effects of strategic orientations on technology-and market-based breakthrough innovations. Journal of marketing, 69(2), 42-60.

\section{Appendix A: Factor Analysis with Varimax Rotation}

\begin{tabular}{|c|c|c|c|}
\hline & \multicolumn{2}{|c|}{ Factor* } & \\
\hline Items for independent variable & F1 & $\mathrm{F} 2$ & F3 \\
\hline $\begin{array}{l}\text { We frequently refine the provision of existing products and } \\
\text { services }\end{array}$ & .000 & .852 & .152 \\
\hline $\begin{array}{l}\text { We regularly implement small adoptions to existing products } \\
\text { and services }\end{array}$ & .084 & .610 & .334 \\
\hline $\begin{array}{l}\text { We introduce improved, but existing products and services for } \\
\text { our local market }\end{array}$ & .114 & .800 & .051 \\
\hline Our organization expands services for existing clients & .052 & .774 & .123 \\
\hline We use sophisticated technology in developing new products & .112 & .322 & .633 \\
\hline $\begin{array}{c}\text { Technological innovation which is undertaken based on } \\
\text { concrete results of a research work, is easily accepted in our } \\
\text { organization }\end{array}$ & .218 & .187 & .860 \\
\hline $\begin{array}{l}\text { Technological innovation is easily accepted in the management } \\
\text { of specific projects undertaken in organizations. }\end{array}$ & .221 & .090 & .890 \\
\hline $\begin{array}{l}\text { The employs have the ability to structure and use newly } \\
\text { collected information }\end{array}$ & .843 & .057 & .096 \\
\hline $\begin{array}{l}\text { The employs are used to preparing newly collected information } \\
\text { for further purposes and making it available }\end{array}$ & .776 & .057 & .088 \\
\hline $\begin{array}{l}\text { The employs are able to integrate new information into their } \\
\text { work }\end{array}$ & .871 & .053 & .096 \\
\hline $\begin{array}{l}\text { The employs have immediate access to stored information, e.g. } \\
\text { about new or changed guidelines or instructions }\end{array}$ & .759 & .105 & .115 \\
\hline $\begin{array}{l}\text { The employs regularly engage in the development of } \\
\text { prototypes or new concepts }\end{array}$ & .785 & .044 & .188 \\
\hline $\begin{array}{l}\text { The employs apply new knowledge in the workplace to } \\
\text { respond quickly to environment changes }\end{array}$ & .835 & .049 & .217 \\
\hline
\end{tabular}

${ }^{*}$ Underlying the dimension as three factor: F1- Realized Absorptive Capability; F2-Exploitative Innovation; F3- Technology Orientation 